\title{
Effectiveness and Safety of Tunneled Pleural Catheter Placement in Patients with Malignant Pleural Effusions
}

\author{
Francisco León-Román*, Beatriz Pintado-Cort, Diana Chiluiza-Reyes, Edwin Mercedes- \\ Noboa, Carmen Rodriguez-Calle, Diurbis Velasco-Álvarez, Andrea Pérez-Figuera, \\ Esther Barbero-Herranz, Paola Arrieta-Narváez, Carlos Almonacid-Sánchez, Andrés \\ Quezada-Loaiza, Beatriz Prieto-González and Deisy Barrios-Barreto
}

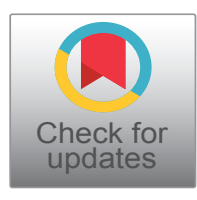

Pneumology Department, University Hospital Ramón y Cajal, IRYCIS, Madrid, Spain

*Corresponding author: Francisco León-Román, Pneumology Department, University Hospital Ramón y Cajal, IRYCIS, Madrid, Spain

\section{Introduction}

Malignant pleural effusion (PE) is a frequent complication that worsens the quality of life and prognosis of patients with end-stage oncologic disease. Preceded only by parapneumonic $P E$, malignancy is one of the most common causes of pleural exudates and lung cancer accounts for as much as $37 \%$ of these cases $[1,2]$. In Europe, approximately 100,000 patients with lung cancer develop PE every year and these patients have an average survival of 4 to 7 months $[3,4]$. Dyspnea is the most frequent symptom in malignant $\mathrm{PE}$ occurring in over $50 \%$ of cases [5]. Patients can also experience discomfort, chest pain, cough, constitutional symptoms and underlying tumor manifestations such as hemoptysis, among others, which can significantly reduce their quality of life $[6,7]$.

The treatment of recurrent malignant PE is usually palliative, so it is advisable to use minimally invasive measures for its management [8]. There are several techniques to treat malignant $P E$, including repeated thoracocentesis and thoracoscopic talc poudrage [1,9]. Systemic treatments (chemotherapy, hormone therapy or radiotherapy) may also control the PE in specific tumors like lymphoma, breast cancer or small cell lung cancer [7].

Tunneled pleural catheters (TPC) have become a new strategy in the treatment of malignant PE, since they are usually placed in an outpatient setting without significant complications, improve quality of life, and can be easily managed at home $[7,10]$. We aimed to review our experience with TPC use assessing the outcomes of patients who got this intervention.

\section{Material and Methods}

We performed a retrospective chart review of 26 consecutive patients with recurrent malignant pleural effusion despite pleurodesis and patients diagnosed with trapped lung who were treated with TPC (PleurX ${ }^{\circledR}$ ) between January 2016 and November 2018 in the Respiratory Department of a tertiary care university hospital in Spain.

An analysis was done regarding patients and pleural effusion characteristics, tumor origin, symptomatolgy, quality of life, complications of the techniques, prognosis, and survival. This information was obtained through review of electronic medical records.

We used the modified scale of the Medical Research Council (mMRC) to assess for degree of dyspnea, the scale of the Eastern Cooperative Oncology Group (ECOG) to measure the functional capacity of the patients and the LENT score (prognostic score for malignant PE) to evaluate the mortality risk. The descriptive analyses of the different variables are presented as means, standard deviation (SD) and interquartile range. The binary data is expressed by abso-

\footnotetext{
Citation: León-Román F, Pintado-Cort B, Chiluiza-Reyes D, Mercedes-Noboa E, Rodriguez-Calle C, et al. (2019) Effectiveness and Safety of Tunneled Pleural Catheter Placement in Patients with Malignant Pleural Effusions. Int J Respir Pulm Med 6:119. doi.org/10.23937/2378-3516/1410119 Accepted: September 24, 2019; Published: September 26, 2019

Copyright: (c) 2019 León-Román F, et al. This is an open-access article distributed under the terms of the Creative Commons Attribution License, which permits unrestricted use, distribution, and reproduction in any medium, provided the original author and source are credited
} 


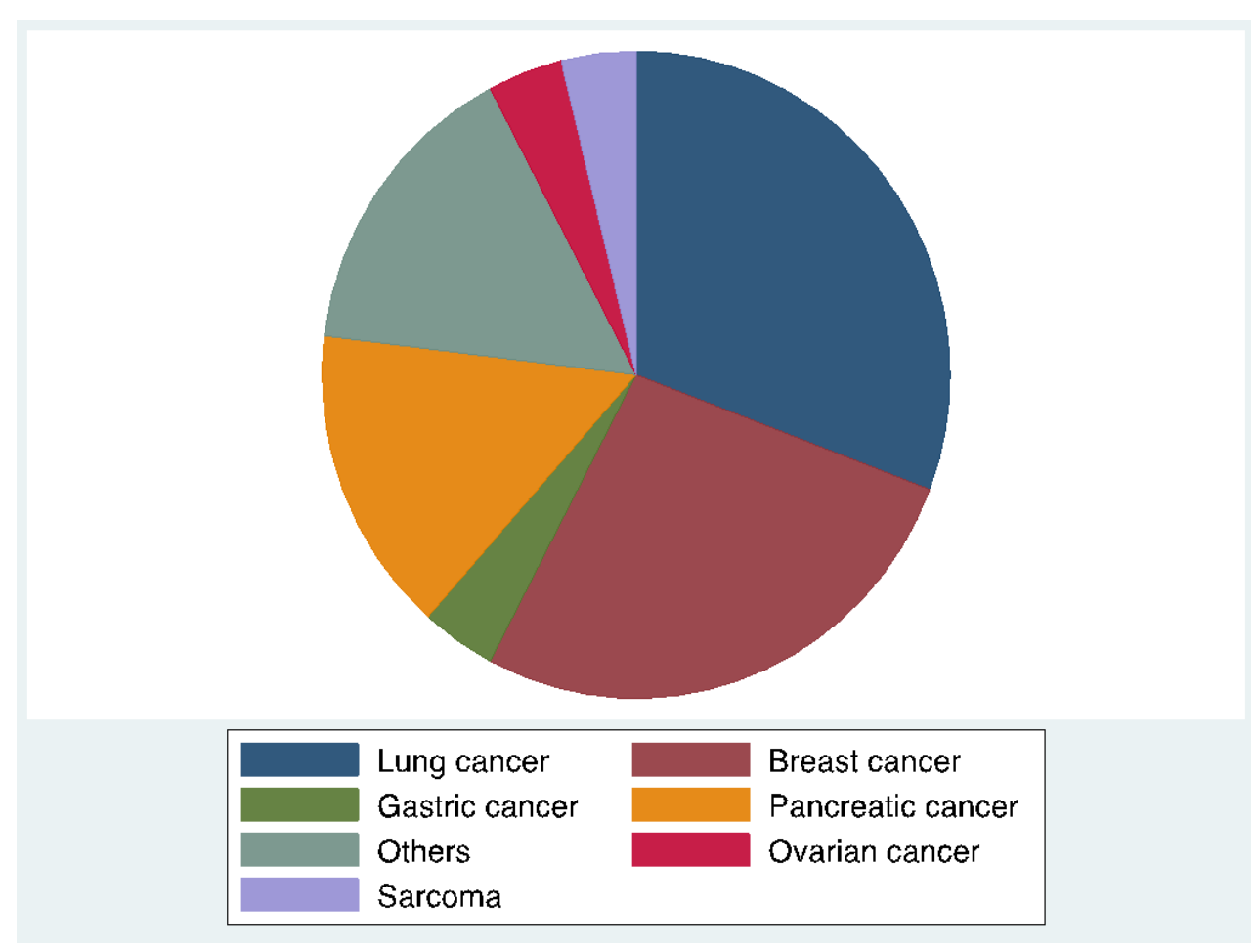

Figure 1: Frequency of the tumor origin of the malignant pleural effusion.

lute and relative frequencies. The assumption of normality in continuous variables was evaluated by the Shapiro-Wilk method.

We used T-student (paired sample T-test to compare the degree of dyspnea before and after the TPC) for normal distributions and Mann-Whitney for non-normal distributions of continuous data. The statistical significance is defined as $p<0.05$. The Stata14 software (StataCorp LLC) was used for the analyses.

\section{Results}

A total of 26 patients with malignant PE were enrolled. Out of these, 12 (46\%) women and 14 (54\%) men, with an average age of $66.5 \pm 17.2$ years. $77 \%$ of the patients were referred by the oncology department.

According to the mMRC dyspnea scale, 23 (88\%; $95 \%$ confidence interval $[\mathrm{Cl}], 70-98 \%)$ patients had grade 3 dyspnea, and $3(12 \%)$ patients had grade 2 dyspnea. Sixty five percent $(17 / 26)$ of the patients had an ECOG of 1 or 2, 27\% (17/26) had an ECOG of 3 or 4 , and only $8 \%(2 / 26)$ had an ECOG of $0.77 \%$ of the patients included had a LENT score with moderate risk and 23\% of high risk.

On chest radiography, $82 \%$ of patients $(24 / 26)$ had $>30 \%$ volume of hemithorax occupation due to a PE. Lung carcinoma $(31 \%)$ and breast cancer were the most common malignancies in this patient population (Figure 1).

The indication for implantation of the TPC in 5 patients (19\%) was recurrent PE after talc pleurodesis. In the remainder of the patients (21), the indication for TPC was recurrent malignant PE in trapped lung.

TPC was placed in an outpatient setting in $20(77 \%)$ of the 26 patients and $6(23 \%)$ were implanted in the inpatient setting a median of 1 day (range 1-5) after hospital admission.

After TPC placement, there was a statistically significant decrease in the dyspnea scale (3.19 vs. 1.96; $p$ $<0.0001$ ) (Table 1). Immediately after TPC placement, one patient $(3.8 \% ; 95 \% \mathrm{Cl}, 0.1-20 \%)$ experienced a complication associated with local anesthetic, consisting of tonic-clonic seizures that responded well to specific treatment (Table 2). None of the patients died during or after the procedure.

The median time from placement of the TPC to removal was 114 days (range 14-155).

Median survival after TPC placement was 96 days (range, 33 to 243 days). $46 \%$ of patients died from causes unrelated to the TPC.

\section{Discussion}

The placement of TPC has been an effective and safe measure for the symptomatic control of recurrent malignant PE in the 26 involved patients with endstage oncologic disease.

These data agree with previous studies that reflect that TPC placement is associated with symptomatic and quality of life improvement in patients with malignant PE $[10,11]$. Lung cancer was the most frequently associated neoplasm with malignant $\mathrm{PE}$, which coincides with several studies in which lung cancer is iden- 
Table 1: Dyspnea grades before and after the insertion of the tunneled pleural catheter.

\begin{tabular}{|l|l|l|l|}
\hline Dyspnea grade* pre-TPC & $\mathbf{N}=\mathbf{2 6}$ & Dyspnea grade* post-TPC & $\mathbf{N = \mathbf { 2 6 }}$ \\
\hline 1 & 0 & 1 & $7(27 \%)$ \\
\hline 2 & $3(11 \%)$ & 2 & $14(54 \%)$ \\
\hline 3 & $15(58 \%)$ & 3 & $4(15 \%)$ \\
\hline 4 & $8(31 \%)$ & 4 & $1(4 \%)$ \\
\hline Mean dyspnea decrease pre-TPC & $\mathbf{3 . 1 9}$ & Mean dyspnea decrease post-TPC & $\mathbf{1 . 9 6}$ \\
\hline p-value $<\mathbf{0 . 0 0 0 1}$ & & & \\
\hline
\end{tabular}

*Dyspnea has been assessed using the mMRC (modified Medical Research Council) scale.

Table 2: Complications after insertion of the tunneled pleural catheter.

\begin{tabular}{|l|l|}
\hline Complications & Catheter number $\mathbf{n}=\mathbf{2 6}$ (\%) \\
\hline During the procedure & \multicolumn{2}{|l|}{} \\
\hline No complication & $25(96.2 \%)$ \\
\hline $\begin{array}{l}\text { Associated with local } \\
\text { anesthetic }\end{array}$ & $1(3.8 \%)$ \\
\hline Early complications (1-7 days post-catheter) \\
\hline Pneumothorax & $1(3.8 \%)$ \\
\hline Pain & $1(3.8 \%)$ \\
\hline Late complications (>7 days post-catheter) \\
\hline Catheter dislocation & $1(3.8 \%)$ \\
\hline Catheter obstruction & $3(11.5 \%)$ \\
\hline Metastatic implant & $1(3.8 \%)$ \\
\hline Empyema & $1(3.8 \%)$ \\
\hline Catheter patency & \\
\hline Functional & $26(100 \%)$ \\
\hline
\end{tabular}

tified as the neoplasm that is associated with more than $30 \%$ of cases of malignant PE [2]. Malignant PE is also identified in more than $90 \%$ of patients with mesothelioma [12].

The implantation of a TPC was successful in $100 \%$ of the cases with adequate subsequent function. TPC has been described to be a safe technique with an incidence of pleural infection of less than $5 \%$ and an adequate response to antibiotic treatment (risk of death below $0.3 \%$ ) $[12,13]$. Other reported complications are pneumothorax, pain or malignant seeding along the insertion tract [7]. In our study, there was only one case with a complication associated with local anesthetic after TPC placement, as well as a low incidence of postoperative complications, with catheter obstruction being the most frequent one, which strengthens the evidence on safety of the technique reported in other studies $[6,7,14]$.

The survival median from the placement of the TPC was 96 days (range 33-243), which is higher than several studies previously conducted in Spain [15].

Finally, $46 \%$ of the patients involved in the study have died from causes unrelated to the TPC such as progression of the underlying disease.
The following limitations of the study are worth mentioning. It was a retrospective, single-center, uncontrolled study with a small sample size. These limitations could be addressed in future prospective randomized, controlled studies.

\section{Conclusions}

TPC placement is a safe and effective approach to the treatment of malignant PE that may provide symptomatic relief and improved quality of life. TPC can be placed in an outpatient setting with infrequent complications associated to the technique. Future larger, randomized-controlled studies could help evaluating this therapy's safety and benefits compared to other frequently used methods such as pleurodesis.

\section{Anowledgements}

We thank Ismael Carrillo-Martin MD for his valuable input in the discussion of the results and proofreading of the manuscript.

\section{References}

1. Feller-Kopman DJ, Reddy CB, DeCamp MM, Diekemper RL, Gould MK, et al. (2018) Management of malignant pleural effusions. An official ATS/STS/STR clinical practice guideline. Am J Respir Crit Care Med 198: 839-849.

2. Shojaee S, Singh I, Solsky I, Nana-Sinkam P (2019) Malignant pleural effusion at presentation in patients with small-cell lung cancer. Respiration 98: 198-202.

3. Mishra E, Davies HE, Lee Y (2009) Malignant pleural disease in primary lung cancer. In: Sprio SG, Huber RM, Janes SM, Thoracic Malignancies. European Respiratory Society Journals Ltd, UK, 313-318.

4. Porcel JM, Gasol A, Bielsa S, Civit C, Light RW, et al. (2015) Clinical features and survival of lung cancer patients with pleural effusions. Respirology 20: 654-659.

5. Chernow B, Sahn SA (1977) Carcinomatous involvement of the pleura: An analysis of 96 patients. Am J Med 63: 695-702.

6. Gupta SS, Floudas CS, Chandra AB (2018) A comparison between two types of indwelling pleural catheters for management of malignant pleural effusions. J Thorac Dis 10: 2976-2980.

7. Asciak R, Rahman NM (2018) Malignant pleural effusion: From diagnostics to therapeutics. Clin Chest Med 39: 181193.

8. Meier M, Mortensen MR, Larsen LU (2016) Implantation 
of permanent pleural catheter for palliation of malignant pleural effusion. Cancer Manag Res 8: 129-133.

9. Seijo L, Campo A, Alcaide AB, Lacunza MM, Armendáriz $A C$, et al. (2006) Manejo ambulatorio del derrame pleural maligno mediante colocación de un catéter de drenaje tunelizado. Experiencia preliminar. Arch Bronconeumol 42: 660-662.

10. Davies HE, Mishra EK, Kahan BC, Wrightson JM, Stanton $A E$, et al. (2012) Effect of an indwelling pleural catheter vs chest tube and talc pleurodesis for relieving dyspnea in patients with malignant pleural effusion: The TIME2 randomized controlled trial. JAMA. 307: 2383-2389.

11. Páez-Codeso FM, Dorado-Galindo A, Jiménez- Fernández DM, Bermejo-Casero E, Ruarte-Naranjo C, et al. (2017) Tratamiento paliativo ambulatorio de disnea con catéter pleural tunelizado en derrame pleural malign. Estudio descriptivo. Neumol Cir Torax 76: 308-314.

12. Psallidas I, Kalomenidis I, Porcel JM, Robinson BW, Stathopoulos GT (2016) Malignant pleural effusion: From bench to bedside. Eur Respir Rev 25: 189-198.

13. Aboudara M, Maldonado $F$ (2019) Update in the Management of pleural effusions. Med Clin North Am 103: 475-485.

14. de Abreu I, Bina Biazzotto AF, Santos MA, de Souza AAC, Abrao FC, et al. (2019) The low-cost, long-term indwelling pleural catheter (LunGO): An inexpensive and effective alternative for the management of dyspnea associated with malignant pleural effusions. Respiration 98: 151-156.

15. Cases E, Seijo L, Disdier C, Lorenzo MJ, Cordovilla R, et al. (2009) Uso del drenaje pleural permanente en el manejo ambulatorio del derrame pleural maligno recidivante. Arch Bronconeumol 45: 575-624. 